\title{
緑のイベント時におけるオープンガーデンの位置づけ
}

\section{A Study on the Significance of 'Open Garden' in a Greenery Event}

\author{
野中 勝利 ${ }^{*}$ \\ Katsutoshi NONAKA
}

\begin{abstract}
Obuse town is the first case of 'Open Garden', that is to open the private residential are with well decorated gardens, in cooperation with the administration office. The aim of this study is to investigate the meaning and significance of 'Open Garden' in Obuse town celebration of "flowers and greenery". This study adopted a questionnaire survey among the visitors at the greenery event, and 275 visitors responded. I concluded the following, based on my analysis of the questionnaire results: the addition of open gardens which are open to the public all year round to the event clearly diversified the range of activities available to the visitors. Even those visitors who did not intend to see the open gardens dropped by the gardens during their walks through the town. Although the open gardens which receive many visitors are usually concentrated around tourist attractions, they are distributed across relatively a wide area. Shuttle bus service and the distribution of information through free brochures made it easier for people to visit the open gardens. The synergy between the greenery event and 'Open Garden' led to the diversification of the activities enjoyed by the visitors, and, as a result, the event was enriched.
\end{abstract}

Keywords: open garden, visitor, behavioral characteristic, Obuse town キーワード：オープンガーデン, 来訪者, 行動特性, 小布施町

\section{1. 研究の目的と方法}

各地で花や緑をテーマとしたイベントや事業が行われている。 適切な季節の特性という性格から，多くは期間限定となり，その 間に各種の催しが開かれる。

オープンガーデンもそのうちの一つである。オープンガーデン は, 一定の地域内で, 指定した公開日時に私的庭園を開放し, 特 定あるいは不特定の観賞者を受け入れる仕組みである。ガーデニ ングの愛好家仲間が中心となって進めているケースもあれば，自 治体が事務局となって運営しているケースもある。また期間や観 賞者を限定する場合や限定しない場合もあり，その形態は様々で ある。

本稿で取り上げる小布施オープンガーデンは, 町役場が事務局 となり運営しているオープンガーデンであり, 2000 年から始め られた。事務局が毎年ガイドブックを作成し, 現在ではそれを有 償頒布している。そこに掲載されている公開庭の情報をみると, 観賞期間は概ね「春〜秋」, あるいは「通年」となっており，特 に公開日時を限定していない。また観賞にあたっては事前連絡を 必要としていない。不特定の観賞者をほぼ通年的に受け入れてい ることになる。

一方，小布施町では緑をテーマとしたイベントを毎年のように 行っている。特定日に町内各地で花・緑関連の各種の催しを集中 させ，誘客を図っている。2004 年は，町制 50 周年を迎え， 9 月 25 日（土）と 26 日（日）の二日間, 農産物や加工品, 花の直販, ガーデニングめぐりなどの催しを集中させた“信州おぶせ緑のか け橋まつり”（以下，「緑のまつり」と略すことがある）を行った。 小布施町での緑関連のイベントでは年間最大の規模であり, 特に 来訪者が集中する。

オープンガーデンは「緑のまつり」の各種イベントのうち, 「おぶせ花めぐり」と称して, そのうちの一つに位置づけられて いる。すなわち期間限定のイベントの中に, 通年的な仕組みであ るオープンガーデンが含有されていることになる。
またこの二日間に限り, 町内をまわる環状線と中央線の二路線 のシャトルバスが運行された。公共駐車場, 駅, イベント会場や 主要観光施設はもとより, 町内に散在する公開庭巡りのために来 訪者の便宜が図られている。バスは有料であるが，一般住宅地な どにも多い公開庭への訪問では公共交通機関がなく, またそのた めの駐車場が設けられていないため, 公開庭巡りに対する利便性 は高い。したがってこの二日間は, オープンガーデンを主目的と した来訪者ではなく，目的としていなかった来訪者も，イベント や観光拠点巡りの中でオープンガーデンによる公開庭を観賞する ことが想定される。

通常は, オープンガーデンの公開庭を観賞するには, 当該年度 に発行されたガイドブックを入手する必要がある。特に公開庭は 年によって多少の増減があり, 最新のガイドブックによる情報入

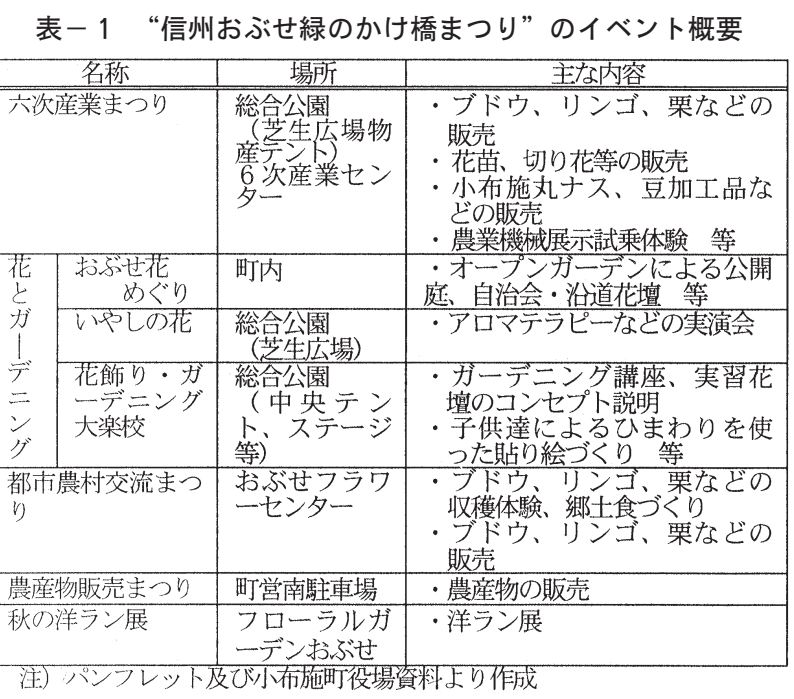


手が必要なためである。2004 年版のガイドブックである『小布 施オープンガーデンブック 2004』（以下，『ブック』とする）は， 有償 (200 円／冊）であり, 公開庭の観賞が明白な場合にこれを 購入し，その情報を入手することになる。ところが，この「緑の まつり」に関しては, B 3 判両面のパンフレット中の町内地図に は, イベント開催場所の位置に加え, 公開庭の位置も記入されて いる。このパンフレットは無料であり, ほとんどの来訪者が手に することが見込まれ, パンフレットを読めば, 公開庭めぐりが容 易になる。個々の公開庭の情報量は, 『ブック』に比べれば少な いが，観賞時における注意事項や公開庭の見ごろの季節が色別に 示され，来訪者への最低限の情報が提供されている。

そこで本稿ではこの「緑のまつり」開催日の来訪者の目的や行 動等から，このイベント時におけるオープンガーデンの意義や位 置づけを明らかにすることを目的とする。

これまでオープンガーデンに関する研究として, 小布施を対象 としてその効果之課題が明らかにされている ${ }^{1)}$ ほか, オープンガー デンの意義 ${ }^{2}$ や経済効果 ${ }^{3)}$ についての既往研究がある。ただし関 連する事業との関係からみた意義や位置づけは明らかにされてい ない。

一方, 小布施を対象としてオープンガーデンによる公開庭の観 賞者の行動特性を明らかにした先行研究 ${ }^{4)}$ がある。オープンガー デンによる公開庭の観賞者を対象として, 『ブック』に添付した 葉書によるアンケート調査による研究（以下，『ブック』調査, とする) である。この『ブック』調査は，有償である『ブック』 を買い求めた, 公開庭の観賞を主目的とした来訪者を対象として おり, 本研究の対象者とは異なる。特に『ブック』調査における 分析対象者には,「緑のまつり」開催日での来訪者が含まれてい ないことが確認され，明らかに区別できる。また「緑のまつり」 の各種イベントの一つに位置づけられ ${ }^{5)}$, シャトルバスの運行や 無償のパンフレットによる情報提供など，通常期のオープンガー デンとは異なる。本稿は, 『ブック』調查とは目的も違うが, こ の『ブック』調査において明らかになった観賞者の行動特性と, 本稿で対象とする来訪者の行動との比較をすることによって, 「緑のまつり」のイベント開催時におけるオープンガーデンの位 置づけをより特徴づけることができる。

調査方法として来訪者に対するアンケート調査を行った。来訪 者に対しアンケート票を直接手渡し, それを当日回収することに した。その箇所は図 1 に示す通りである。

配布する (手渡す) 場所は, 来訪者の町内での起点となること が想定される町営駐車場や駅のほか, 観光拠点施設とした。特に この「緑のまつり」開催期間中に運行されるシャトルバスの切符 を販売する拠点施設を網羅した。計 13 箇所である。これは町内 を移動する来訪者を対象とするためである。総合公園では最も多

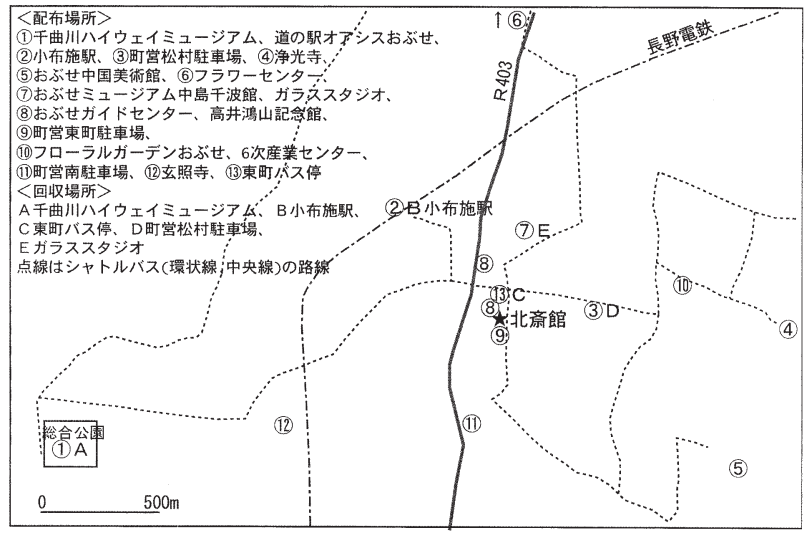

図ー1 アンケート票の配布・回収場所
くのイベントが開催され，この場所のみに滞在する来訪者も多い。 しかし公開庭巡りをする可能性のある来訪者を調査対象とするた め,このような方法を採った。

回収場所は，来訪者が自動車あるいは鉄道を利用することが見 込まれることから，A．千曲川ハイウェイミュージアム， B．小 布施駅， C. 町営松村駐車場に加え, 町内で最も集客力のある観 光拠点である北斎館の最寄りのシャトルバスのバス停である, D. 東町バス停の 4 箇所とした。

\section{2.アンケート票の配布・回収}

回収されたアンケートの回答数は，9月 25 日が 143 票，9月 26 日が 132 票, 計 275 票であった。

配布場所と回収場所別のアンケート回答数は表 2 に示す通りで ある。なお 25 日と 26 日の回答数には際立った差異がみられない ことから，合わせた 275 票の回答をもとに分析をすることとした。 なおこの中には小布施町民 4 人からの回答も含まれており, 適宜, 分析内容に応じて，その対象から町民を除いている。

回収されたアンケート票の配布場所では, 町営松村駐車場が最 屯多く, 次いで小布施駅, 千曲川八イウェイミュージアムとなっ ている。回収場所では, 町営松村駐車場が最も多く, 次いで東町 バス停，小布施駅となっている。

配布と回収の場所から回答者の動向をみると, 最も多いのは町 営松村駐車場で配布・回収した回答であり, 次いで小布施駅での 配布・回収となっている。

なお配布数が確認できた 4 箇所で配布されたアンケート票のう ち, いずれかの場所で回収された数をもとに回収率をみると表 3 のようになる。平均で $21.7 \%$ 回収率となっている。この 4 箇 所で配布したアンケート票の回収数は 229 票であり, 全体の回収 数 275 票の $83.3 \%$ となる。したがって全体としては，概ね 2 割 程度の回収率と推察される ${ }^{6)}$ 。

\section{3.小布施町を訪れた回数と目的}

小布施町を訪れた回数では (表 4), 半数近くが初めてである が, 逆に 2 回以上訪れている回答者が半数以上いることになり, 再訪者（リピーター）が多いことが特徴である。特に 5 回め以上 である回答者が 2 割近くいる。

小布施町を訪れた目的では（表 5 ),「まち並み」が最も多く, 次いで「北斎館」であった。全体でみれば，回答者の 7 割以上は

\section{表 -2 配布・回収場所別のアンケート回収数}

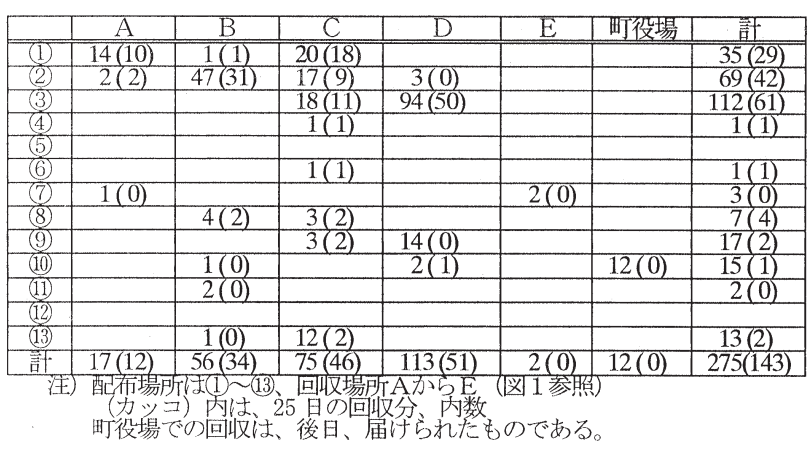

表－３アンケート票の回収率

\begin{tabular}{|l|r|r|r|}
\hline \multicolumn{1}{|c|}{ 配布場所 } & 配布数 & 回収数 & 回収率 \% \\
\hline \hline (1)干曲川ハイウエイミージム & 210 & 35 & 16.7 \\
\hline (2)小布施駅 & 289 & 69 & 23.9 \\
\hline (3)田営松村駐車場 & 527 & 112 & 21.3 \\
\hline (4)東町バス停 & 29 & 13 & 44.8 \\
\hline \multicolumn{2}{|r}{} \\
\hline
\end{tabular}


「緑のまつり」に関連したイベントへの目的者ではなかった。 「その他」を挙げている回答者が $1 / 3$ いる。その自由記入欄を見 ると, 栗, 栗菓子, そば，酒等の飲食を挙げている回答が多い。

オープンガーデンを目的としている回答者は約 $15 \%$ の 42 人で ある。後述のように, オープンガーデンの訪問は 142 人 (小布施 町民 2 人を除く）いる。当初, オープンガーデンを目的としてい なくても, 町内を遊覧している途中で公開庭を観賞している人が 多いことがわかる。町内の移動する来訪者を対象とした今回の調 査では,「緑のまつり」の各種イベントのうち, このオープンガー デンへの参加を目的とする回答者が最も多い。

\section{4 、情報入手の方法}

「信州おぶせ緑のかけ橋まつり」の概要情報, そしてオープン ガーデンという取り組みの情報をどのように知ったのかを尋ねた (表 7 )。

まず「緑のまつり」では「知人・ロコミ」が 2 割弱いて最も多 い。このほか,「新聞・雑誌」「パンフ・ポスター」の順になって おり, 事前の情報入手の方法がわかる。また「観光案内所」も多 いがこれは小布施町を訪れて知ったことになる。「知らなかっ た」という回答, 約 $6 \%$ を加えると, 2 割の回答者が事前には知 らず，小布施町に来てこのイベントが開催されていることを知っ たのである。逆にみれば, イベントの開催とは関係なく, 小布施 町への来訪者が存在していることがわかる。

一方, 特に「小布施オープンガーデン」という取り組みの情報 についても，ほぼ上記と同様の入手方法の比率となっている。

\section{表 -4 小布施町の訪問回数}

\begin{tabular}{|c|c|c|}
\hline & \multicolumn{2}{|c|}{ 回答数 } \\
\hline 初めर & 128 & 47.2 \\
\hline 2 回 & 39 & 14.4 \\
\hline 3 回 & 26 & 9.6 \\
\hline $4 \sqrt{1} \delta$ & 17 & 6.3 \\
\hline 5 可以 & 50 & 18.5 \\
\hline 不明 & 11 & 4.1 \\
\hline & 271 & 100.0 \\
\hline
\end{tabular}

表一 5 小布施町を訪れた当初の目的（複数回答）

\begin{tabular}{|c|c|c|c|}
\hline \multicolumn{2}{|r|}{ 目的 } & \multicolumn{2}{|c|}{ 回答数 } \\
\hline \multirow{5}{*}{$\begin{array}{l}\text { 信州おふぶせ緑の } \\
\text { か、橋まつり }\end{array}$} & 六次産業まつり & 7 & 2.6 \\
\hline & オープンガーデン & 42 & 15.5 \\
\hline & ガーデニング大楽校 & 2 & 0.7 \\
\hline & 都市農村交流まつり & 2 & 0.7 \\
\hline & フローラルガーデン & 24 & 8.9 \\
\hline \multicolumn{2}{|l|}{ 北斎館 } & 88 & 32.5 \\
\hline \multicolumn{2}{|l|}{ まち並汃 } & 116 & 42.8 \\
\hline \multicolumn{2}{|l|}{ その他 } & 91 & 33.6 \\
\hline \multicolumn{2}{|l|}{ 不明 } & 11 & 4.1 \\
\hline
\end{tabular}

注）小布施町民4 人を除人

表一 6 オープンガーデン有無別の当初の目的（複数回答）

\begin{tabular}{|c|c|c|c|c|c|}
\hline \multirow{9}{*}{$\begin{array}{l}\text { オープンカ゚ーデン } \\
\text { 目的としている }\end{array}$} & \multicolumn{2}{|l|}{ 回答 } & 他の目的 & \multicolumn{2}{|l|}{ 回答 } \\
\hline & 42 & 15.5 & なし & 13 & 4.8 \\
\hline & & & 空次产業まつり & 4 & 1.5 \\
\hline & & & ガーデニング大楽校 & 0 & \\
\hline & & & 都市農村交流まつり & 2 & 0.7 \\
\hline & & & フローラルガーデン & 10 & 3.7 \\
\hline & & & 北斎館 & 12 & 4.4 \\
\hline & & & まち並み & 12 & 4.4 \\
\hline & & & その他 & 3 & \\
\hline 目的とはして & 218 & 80.4 & 六次産業まつり & 3 & 11 \\
\hline いない & & & ガーデニング大楽校 & 2 & 0.7 \\
\hline & & & 都市農村交流まつり & 0 & \\
\hline & & & フローラルガーデン & 14 & 5.2 \\
\hline & & & 北阁館 & 76 & \\
\hline & & & まち並み & 104 & 38.4 \\
\hline & & & その他 & 88 & 32.5 \\
\hline 不明 & $\frac{11}{39}$ & 4.1 & & & \\
\hline
\end{tabular}

注) 小布施町衣 4 人在除人

\section{5. オープンガーデンの訪問者}

アンケート回答者のうちオープンガーデンによる公開庭を訪問 したのは 144 人であった。回答者の $52.0 \%$ と半数以上である。

このうち小布施町民 2 人を除いた 142 人について, 小布施町及 びオープンガーデンの訪問回数は表 8 に示す通りである。初めて オープンガーデンの公開庭を訪問した回答者は 7 割以上を占めて いる。小布施町への訪問が 2 回め以上の回答者は 132 人いるが (表 4), このうち 60 人が今回初めて公開庭を訪問している。オー プンガーデンが, 再訪者に対する行動の選択肢の重要な一つとなっ ていることがわかる。

次に住所と小布施町までの交通機関を整理すると表 9 のように なる。最も多いのは長野県の 41 人で 3 割弱を占める。次いで, 新潟県, 群馬県となっている。また約 $2 / 3$ が自家用車で小布施 町を訪れていることが特徴的である。特に長野県内及び, 新潟県 や群馬県という隣県から自家用車で来ている。ただしこれは小布 施町への交通手段であり, 駐車場を併設している観光拠点間では 自家用車の利用が想定されるが，オープンガーデンによる公開庭 巡りは，徒歩あるいはシャトルバスの利用となる。

公開庭の訪問者が，よ゙こでアンケート票を受け取り，返却した のかをみると（表 10）, 概㖶配布・回収の傾向（表 2 ） と変わら ない。絶対数からみれば町営松村駐車場（表 10 中の配布(3), 回

表 -7 情報入手の方法（知ったきっかけ）

\begin{tabular}{|l|c|r|r|r|}
\hline \multirow{2}{*}{\multicolumn{2}{c|}{ 入手元 }} & \multicolumn{2}{|c|}{ 緑のまつり } & \multicolumn{2}{c|}{ オープンガーデン } \\
\cline { 2 - 5 } & 回答数 & $\%$ & 回答数 & $\%$ \\
\hline \hline 知人・ロコミ & 52 & 18.9 & 52 & 18.9 \\
\hline 観光案内所 & 41 & 14.9 & 42 & 15.3 \\
\hline 新聞・雑志 & 33 & 12.0 & 37 & 13.5 \\
\hline パンフ・ボスター & 33 & 12.0 & 31 & 11.3 \\
\hline インターネット & 11 & 4.0 & 7 & 2.5 \\
\hline その他 & 39 & 14.2 & 44 & 16.0 \\
\hline 知らなからた & 17 & 6.2 & 13 & 4.7 \\
\hline 不明 & 49 & 17.8 & 49 & 17.8 \\
\hline & 275 & 100.0 & 275 & 100.0 \\
\hline
\end{tabular}

表 -8 小布施町及びオープンガーデンの訪問回数

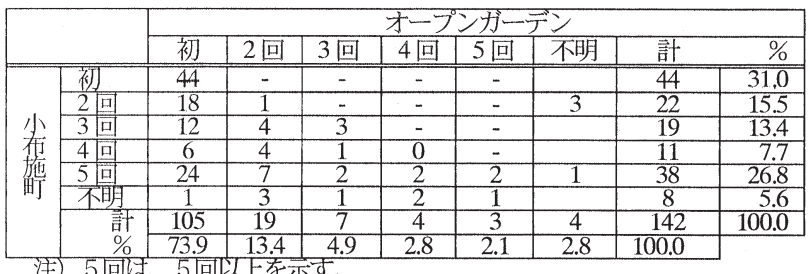

表－9 オープンガーデン訪問者の住所と交通機関

\begin{tabular}{|c|c|c|c|c|c|c|c|c|}
\hline & 自家 & 鉄道 & 然体 & $V_{\text {沙 }}$ & 巟の & 不明 & \multicolumn{2}{|l|}{ 計 } \\
\hline 長野県 & 39 & 2 & & & & & 41 & 28.9 \\
\hline 菄京都 & 2 & 10 & & & & & 12 & 8.5 \\
\hline 新潟県 & 14 & 1 & & & & & 15 & 10.6 \\
\hline 群馬県 & 8 & 2 & & 1 & & & 11 & 7.7 \\
\hline 票知県 & 3 & 2 & & 2 & & & 7 & 4.9 \\
\hline 于葉背 & 1 & 2 & & & 1 & & 4 & 2.8 \\
\hline 埼玉県 & 2 & 3 & & & & & 5 & 3.5 \\
\hline 神奈川県 & 1 & & & & & & 1 & 0.7 \\
\hline 富山県 & 1 & & & & & & 1 & 0.7 \\
\hline 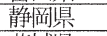 & 1 & 1 & 1 & & & & 3 & 2.1 \\
\hline 茨城県 & 1 & & & & & & 1 & 0.7 \\
\hline 重県 & 1 & & 2 & & & & 3 & 2.1 \\
\hline 京都府 & 1 & 2 & & & & & 1 & 0.7 \\
\hline 杤木県 & & & 1 & & & & 1 & 0.7 \\
\hline 岐阜県 & & 1 & & & & & 1 & 0.7 \\
\hline 福岡県 & 1 & & & & & & 1 & 0.7 \\
\hline & 1 & & & & & & 1 & 0.7 \\
\hline 山梨県 & 1 & & & & & & 1 & 0.7 \\
\hline 滋賀県 & & 1 & & & & & 1 & 0.7 \\
\hline 不明 & 16 & 6 & 2 & 2 & 1 & 1 & 28 & 0.7 \\
\hline 計 & 94 & 34 & 6 & 5 & 2 & 1 & 142 & 100.0 \\
\hline & 66.2 & 23.9 & 4.2 & 3.5 & 1.4 & 0.7 & 100.0 & \\
\hline
\end{tabular}


収D）で配布・回収されたアンケート票が多い。東町バス停での 回収数（表 10 中の C ）は配布数に比へ比較的多く,これはシャ トルバスで帰る際に返却しているためとみられる。

\section{表一10 オープンガーデン訪問者の配布・回収場所}

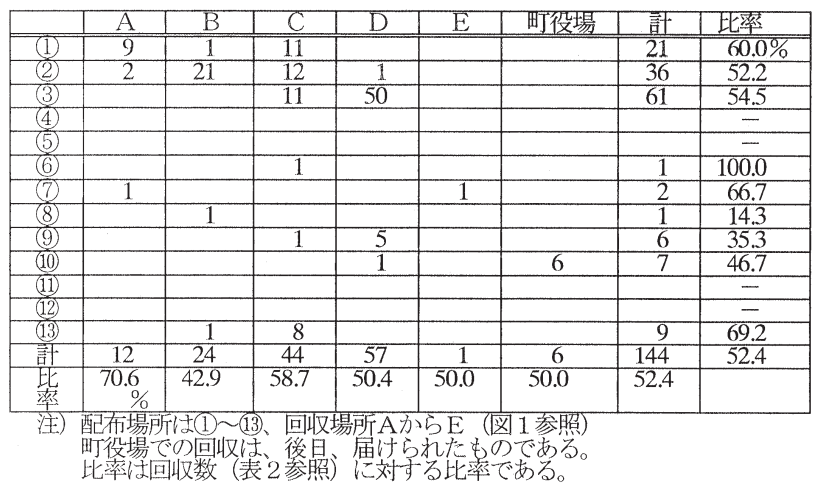

\section{6. オープンガーデンの観賞実態}

オープンガーデンを訪問したという回答者は 144 人いたが，そ のうち具体的に観賞した公開庭の箇所を記入した回答者は 55 人 であった（表 11）。なおこの 55 人の同行者の数をあわせると， 計 157 人分の観賞行動を捕捉することになる。

当初の目的をみると（表 12 )，オープンガーデンを目的として いた回答者は 16 人，約 3 割で，そのうち 7 人は公開庭の観賞を 主目的として小布施町を訪れている。オープンガーデンを目的と していなかった回答者 38 人の目的は北斎館やまち並みなどで,

「緑のまつり」に関連するイベントへの参加も目的としていない。 「緑のイベント」の開催に関係なく小布施町に来て, オープンガー デンによる公開庭の観賞をしている。つまり当初の予定外の行動 を採り, 結果として「緑のまつり」のイベントに参加しているこ とになる。

回答者別に観賞した公開庭数をみると, 最少は 1 筒所, 最多は 13 ヶ所であった。ただし 7 箇所以上観賞した回答者は 4 人しか なく，一人当たりの平均観賞公開庭数は，3.4 箇所である。『ブッ

表-11 回答者別の観賞公開庭とその選定理由等

\begin{tabular}{|c|c|c|c|c|c|c|c|c|c|c|c|c|c|c|}
\hline No. 1 & 答省 & 䛷 & & 华㱓 & 住所 & 訲閭 & 回数 & 訪閣目 & 的（複数回答） & オープンガーデン & 司行人数 & 交通機関 & 锥賞公開庭 & 選定理目 \\
\hline & 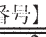 & 饰 & & & & 小布湤 & $\mathrm{OG}$ & 1 & 3 & を知ったきっかけ & (人) & & ([x]内内は『ブック』における公開庭番号) & $\begin{array}{lllll}1 & 2 & 3 & 4 & 5 \\
\end{array}$ \\
\hline 1 & 2 & 1 & $\overline{\mathrm{A}}$ & 60D上 & 長野県 & 3 & $\overline{3}$ & OG & FG & 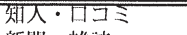 & 5 & 自象用車 & 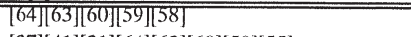 & $\bar{O}$ \\
\hline 2 & 147 & 1 & A & 40代 & 長野眎 & 3 & 2 & $\mathrm{OG}$ & & 新聞・雑誌 & 2 & 自家用車 & {$[37][41][31][64][63][60][59][55]$} & 0 \\
\hline 3 & 17 & 1 & $\mathrm{C}$ & 50代 & 長野県 & 不明 & 2 & $O G$ & $\mathrm{FG}$ & 新聞・杂誰誌 & 2 & 自家用車 & {$[57][56][55][61][64]$} & 0 \\
\hline 4 & 19 & 1 & $\mathrm{C}$ & 40代 & 長野県 & 4 & 2 & $O G$ & 六次等業 F G & 新開・雑誌 & 2 & 自家用車 & {$[55][56][57][64]$} & O \\
\hline 5 & 20 & 1 & $\mathrm{C}$ & 40代 & 長野県 & 3 & 2 & $O G$ & まち並み & 新開・雑誌 & 3 & 自家用車 & [46] & 0 \\
\hline 6 & 22 & 1 & $\mathrm{C}$ & 40代 & 長野県 & 3 & 1 & $O G$ & & テレビ & 3 & 自家用車 & {$[38][37][39][41][64]$} & 0 \\
\hline 7 & 23 & 1 & $\mathrm{C}$ & 40代 & 長野紧 & 4 & 1 & $O G$ & & パンフ・ポスター & 3 & 自家用車 & {$[37][38][41]$} & 0 \\
\hline 8 & 24 & 1 & $\mathrm{C}$ & 50 代 & 長野県 & 1 & 1 & $O G$ & まち並み & 知人・ロコミ & 3 & 自家用車 & [46] & O \\
\hline 9 & 149 & 1 & $\mathrm{C}$ & 50代 & 東京都 & 2 & 1 & $O G$ & & その他 & 2 & 自家用車 & {$[7][8][6][5][3][1][2][38][39][37][41][36][32]$} & 0 \\
\hline 10 & 30 & 2 & A & 40代 & 小布施 & - & - & - & & - & 2 & 徒步 & {$[13][14][15][16]$} & 0 \\
\hline 11 & 33 & 2 & $\mathrm{~B}$ & 30代 & 東京都 & 1 & 1 & 北斎館 & & その他＊ & 2 & 鉄道 & {$[64][63][60]$} & 不明 \\
\hline 12 & 38 & 2 & B & 20 代 & 群馬県 & 1 & 1 & その他 & & 峴光案内所 $*$ & 1 & 鉄道 & $\lceil 64\rceil[60\rceil \mid 58][59\rceil \mid 63]$ & 000 \\
\hline 13 & 53 & 2 & B & 50代 & 兵庫県 & 1 & 1 & 北看館 & まち业み & パンフ・ポスター & 1 & 鉄道 & {$[57][58][59][60]$} & 0 \\
\hline 14 & 54 & 2 & B & 40代 & 埼玉県 & 3 & 1 & その他 & & 観光案内所 & 2 & 鉄道 & {$[62][63][55][57][58][59]$} & 5 \\
\hline 15 & 59 & 2 & B & 50代 & 県外 & 不明 & 3 & $O G$ & $\mathrm{FG}$ & 新聞・椎誌 & 2 & 自家用車 & 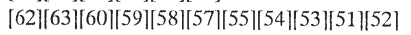 & 0 \\
\hline 16 & 152 & 2 & B & 50代 & 千葉県 & 2 & 不明 & $O G$ & その他 & 新閏・雑誌: & 1 & 鉄道 & {$[46 \mid[29 \mid[34][36][59|| 60 \mid[63]$} & 0 \\
\hline 17 & 157 & 2 & B & 40代 & 埼玉県 & 1 & 1 & その他 & & その他（駅で）＊ & 1 & 鉄道 & {$[46][47][62]$} & 0 \\
\hline 18 & 158 & 2 & B & 40代 & 東京都 & 1 & 1 & まち目少 & & 雃光案内所 $*$ & 2 & 鉄道 & [64] & 不明 \\
\hline 19 & 160 & 2 & B & 60以上 & 群馬県 & 1 & 1 & まち业夕 & & 微光案内所 $*$ & 2 & 鉄道 & {$[58][59][60]$} & 不明 \\
\hline 20 & 164 & 2 & B & 60以上 & 東京都 & 5 & 4 & OG & & テレビ & 1 & 鉄道 & [27] & 不明 \\
\hline 21 & 165 & 2 & $\mathrm{~B}$ & 不明 & 不明 & 1 & 1 & その他 & & 新聞 · 雑誌 & 1 & 鉄道 & [58][59][60] & 0 \\
\hline 22 & 63 & 2 & $\mathrm{C}$ & 60以上 & 千葉県 & 2 & 1 & その他 & & 知人・ロコミ & 7 & 鉄道 & {$[58][59][60][64][63]$} & 0 \\
\hline 23 & 65 & 2 & $\mathrm{C}$ & 不明 & 不明 & 2 & 不明 & 北阁館 & まち並み & 微光案内所 * & 7 & 鉄道 & {$[61][57][58][59][60]$} & 不明 \\
\hline 24 & 66 & 2 & $\mathrm{C}$ & 60以上 & 埼玉県 & 1 & 1 & まち业み & & 新開・杂誰誌 & 7 & 鉄道 & {$[56][60][63][64]$} & 0 \\
\hline 25 & 172 & 2 & $\mathrm{C}$ & 60以上 & : 岐阜県 & 1 & 1 & 北阁館 & まち並み & 和人・ロコミ & 5 & 敛道 & [61] & 不明 \\
\hline 26 & 173 & 2 & $\mathrm{C}$ & 60以上 & 愛知県 & 5 & 1 & 北斎館 & まち业み & 新聞・雑誌 & 6 & 鉄道 & [61][27][64] & 0 \\
\hline 27 & 176 & 2 & D & 60以上 & 嬡知県 & 1 & 1 & まち並み & & インターネット & 6 & レンタカー & {$[58][59][60][63]$} & 不明 \\
\hline 28 & 73 & 3 & $\mathrm{C}$ & 40代 & 京都府 & 10 & 5 & まち业み & その他 & その他 & 2 & 自家用車 & [58][59] & 0 \\
\hline 29 & 84 & 3 & D & 10代 & 硼黑県 & 1 & 1 & まち亚办 & その他 & その他 & 4 & 自家用車. & [64] & 0 \\
\hline 30 & 91 & 3 & D & 10代 & 長野県 & 1 & 1 & 北甪館 & & 知人・口コミ & 3 & 自家用車 & {$[28][69]$} & 0 \\
\hline 31 & 92 & 3 & D & 50代 & 不明 & 2 & 不明 & 北斎館 & & 知人・ロコミ & 3 & 自家用車 & $|64|[17]$ & 0 \\
\hline 32 & 95 & 3 & $\mathrm{D}$ & 50代 & 神奈川 & 1 & 1 & $O G$ & & 知らなかった* & 2 & 自家用車 & [31] & O \\
\hline 33 & 102 & 3 & $\mathrm{D}$ & 40代 & 新渴県 & 5 & 1 & $O G$ & その他 & 新聞・倠誌 & 2 & 自家用車 & $|60|[59 \mid[58][41][32|| 36]$ & 0 \\
\hline 34 & 121 & 3 & D & 40代 & 新潟県 & 6 & 1 & その他 & & その他 & 2 & 自家用車 & [26][29] & 0 \\
\hline 35 & 127 & 3 & D & 20代 & 長野県 & 3 & 1 & まち並み & & パンフ・ポスター & 2 & 自家用車 & {$[58][57]$} & 0 \\
\hline 36 & 128 & 3 & D & 40代 & 捧馬県 & 2 & 2 & まち业み & & パンフ・ポスター & 2 & 自家用車 & [53][58] & 0 \\
\hline 37 & 129 & 3 & D & 30代 & 群馬県 & 3 & 2 & まち业み & & 䘽光案内所 & 2 & 自家用車 & [61||64] & b \\
\hline 38 & 184 & 3 & D & 40代 & 愛知県 & 1 & 1 & まち业み & その他 & パンフ・ポスター & 6 & レンタカー & {$[63][60]$} & 不明 \\
\hline 39 & 185 & 3 & D & 30代 & 東京都 & 5 & 1 & その他 & & インターネット & 3 & 鉄道 & {$[58][59][60]$} & 0 \\
\hline 40 & 186 & 3 & D & 40代 & 長野県 & 不明 & 1 & その他 & & パンフ・ポスター & 3 & 自家用車 & {$[58][59][60]$} & 不明 \\
\hline 41 & 187 & 3 & $\mathrm{D}$ & 50代 & 長野県 & 5 & 1 & まち亚み & & テレビ & 2 & 自家用車 & [37][41] & 0 \\
\hline 42 & 192 & 3 & D & 30代 & 样憑県 & 1 & 1 & その他 & & パンフ・ポスター & 2 & 自家用車 & {$[64][60][63]$} & 0 \\
\hline 43 & 200 & 3 & D & 50代 & 千葉県 & 1 & 1 & まち业み & & その他 & 4 & 自家用車 & [64] & $\mathrm{O}$ \\
\hline 44 & 203 & 3 & $\mathrm{D}$ & 60以上 & 長野県 & 1 & 1 & 北斎館 & まち业为 F G & 新聞・雑誌 & 4 & 自家用車 & {$[57][56][59][60][63][64]$} & 0 \\
\hline 45 & 206 & 3 & $\mathrm{D}$ & 不明 & 不明 & 5 & 不明 & $O G$ & & 新聞・雑誌 & 2 & 自家用車 & [64] & 0 \\
\hline 46 & 215 & 3 & $\mathrm{D}$ & 50代 & 新潟県 & 2 & 1 & まち业的 & その他 & 和らなかった* & 3 & 自家用車 & {$[55][56]$} & 不明 \\
\hline 47 & 217 & 3 & $\mathrm{D}$ & 30代 & 東京都 & 1 & 1 & その他 & & 知らなかった* & 2 & 自家用車 & {$[58][59][60][63][28][69]$} & 0 \\
\hline 48 & 222 & 3 & D & 30代 & 新潟県 & 5 & 1 & その他 & & 知らなかった* & 2 & 自家用車 & {$[69][28][64][63][60]$} & 0 \\
\hline 49 & 225 & 3 & $\mathrm{D}$ & 40代 & 埼玉県 & 1 & 1 & 北斎館 & & パンフ・ポスター & 1 & 自家用車 & {$[60][63][64]$} & 0 \\
\hline 50 & 228 & 7 & $\mathrm{~A}$ & 30代 & 長野県 & 5 & 3 & $O G$ & 六次牵業 & 知人・ロコミ & 4 & 自家用車 & [55] & 00 \\
\hline 51 & 229 & 7 & $\mathrm{E}$ & 30代 & 新潟県 & 2 & 1 & その他 & & 観光案内所 & 2 & 自家用車 & [55] & 不明 \\
\hline 52 & 136 & 8 & B & 30代 & 東京都 & 6 & 1 & まち亚み & その他 & 知人・ロコミ & 1 & 鉄道 & {$[28][69][64]$} & 0 \\
\hline 53 & 237 & 9 & $\mathrm{D}$ & 20代 & 長野临 & 10 & 1 & まち並み & & 新聞・踓䄊 & 2 & 自家用車 & [28][69] & 0 \\
\hline 54 & 268 & 13 & $\mathrm{C}$ & 50)代 & 三重県 & 3 & 1 & その他 & & （不明） & 4 & 自家用車 & [64] & 0 \\
\hline 55 & 275 & 13 & $\mathrm{C}$ & 60以上 & 不明 & 1 & 1 & 北前飭 & & 知人・ロコミ & 5 & 鉄道 & [61] & 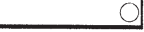 \\
\hline
\end{tabular}


ク』調查の対象者 36 人の一人当たり平均観賞公開庭数が 5.9 箇 所であるのに比べると少ない。当初, オープンガーデンによる公 開庭への訪問が目的としてない回答者が多く, 町内を回遊する途 中で, 公開庭の存在を知り, 足を運んで観賞しているとみられる。 当初の目的にはなかったが, 小布施でオープンガーデンの存在を 知り，予定外の行動をとったのである。

回答者 55 人が観賞した公開庭は, 全 64 箇所のうち 41 箇所で あり, 全体の $64.1 \%$ にたる。公共駐車場, 観光施設や駅から 遠い公開庭へも訪れている。シャトルバスの運行効果とみること ができる。

観賞者数から公開庭をみると, 最多は 22 人の観賞者があった 公開庭である。回答者の 4 割以上, すなわち 22 人以上が観賞し た公開庭は [60］と [64（以下，公開庭を特定する時は『ブッ ク』における公開庭番号を［］示す）の２箇所であった。3 割以上となる 17 人以上の観賞者のあった公開庭は, このほかに 2 箇所（[58）と [59]）あった。一方，1 割以下の 5 人以下の観 賞者数であった公開庭は 32 箇所あり, 観賞された公開庭 41 箇所 の $78.0 \%$ 占める。観賞した公開庭に偏りがあることがわかる。

今回の調査で 1 人でも観賞者のあった 41 箇所の公開庭を地理 的な分布状況からゾーン分けを行うと図 2 のように A Hの 8 つ のゾーンに分けることができる。このうち A と Bのゾーンは, そ れぞれ北斎館に近いが, まち並みの整備地域や地場産品の小売店 や飲食店等の店舗が多く立地している地域を Aゾーンとし, 北斎 館の裏手にあたり, 一般住宅地である地域をBゾーンとしてあえ て分けた。Bゾーンは, 公開庭の観賞を目的としなければ, 一般 の観光客が来ない地域である。

このゾーン分けでより明確になったのは，特に観賞者の多かっ

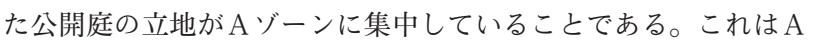
ゾーン内の散策中の立ち寄りとみられる。しかし一方では, 観賞

\section{表-12 オープンガーデン有無別の当初の目的（複数回答）}

\begin{tabular}{|c|c|c|c|c|c|}
\hline オープンガーデン & 回答 & $\%$ & 他の目的 & 回答 & $\%$ \\
\hline \multirow[t]{8}{*}{ 目的としている } & \multirow[t]{8}{*}{16} & \multirow[t]{8}{*}{29.6} & なし & 7 & $\overline{13.0}$ \\
\hline & & & 六次産業まつり & 2 & 3.7 \\
\hline & & & ガーデニング大楽校 & 0 & - \\
\hline & & & 都市農村交流まつり & 4 & - \\
\hline & & & フローラルガーデン & 0 & - \\
\hline & & & 北斎館 & 2 & 3.7 \\
\hline & & & まち並夕 & 2 & 3.7 \\
\hline & & & その他 & 2 & 3.7 \\
\hline \multirow{8}{*}{$\begin{array}{l}\text { 目的しはして } \\
\text { いない }\end{array}$} & \multirow[t]{7}{*}{38} & \multirow[t]{7}{*}{70.4} & 六次产業まつり & 0 & - \\
\hline & & & カjーデニング大楽校 & 0 & - \\
\hline & & & 都市農村交流まつり & 0 & - \\
\hline & & & フローラルガーデン & 1 & 1.9 \\
\hline & & & 北斎館 & 10 & 18.5 \\
\hline & & & まち並夕 & 20 & 37.0 \\
\hline & & & その他 & 18 & 33.3 \\
\hline & 54 & 100.0 & & & \\
\hline
\end{tabular}

注）小布施町民 1 人を除く
者数は少ないが，この二日間に観賞者のいた公開庭は広範囲に分 布している。これらの一般住宅地への移動手段はシャトルバスの 利用とみられる。また訪問するためには場所を示した地図情報が 必要であり,「緑のまつり」の無料パンフレットが活用されたと 考えられる。

次にこの 55 人の回答者が観賞した公開庭の数と，それらを巡 る順序を追跡し，訪れたゾーンの数とを整理したのが表 13 であ る。これは『ブック』調査と比較して, 特徴を明らかにするため, 同調査（表 14）での結果を参照する。

本調査では 1 ゾーン以内の行動者が 42 人, $76.4 \%$ を占める。 『ブック』調査に比べて，行動範囲が狭いことがわかる。しかも 1 ゾーン内の 3 箇所以下の公開庭を観賞した回答者は 30 名, 54.5 \%であり，半数以上となる。一方，観賞した公開庭の数も多く， また訪問したゾーン数が 5 ゾーン以上の行程の回答者は一人もい なかった。

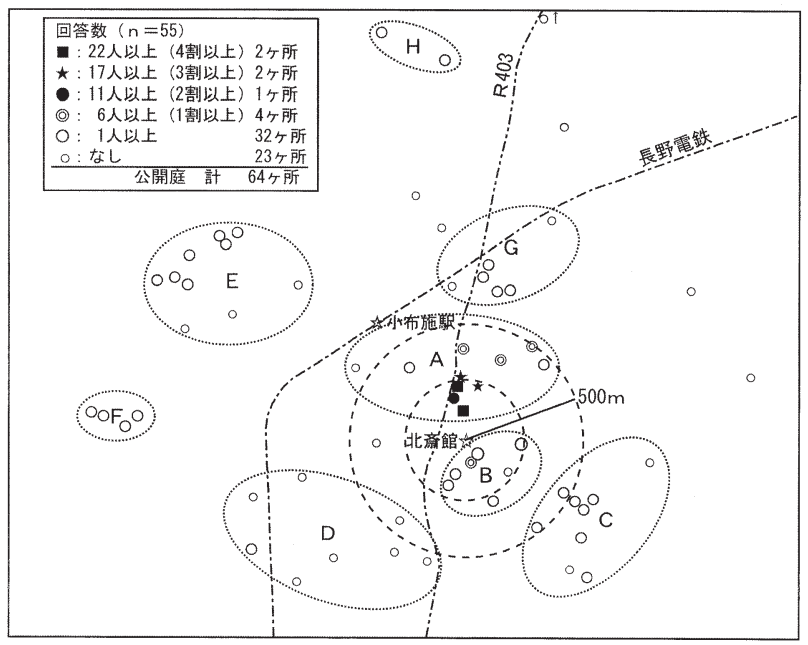

図-2＼cjkstart公開庭別の観賞者数及びゾーン分け

表ー14 『ブック』調査 ${ }^{4}$ における行動別対象人数（人）

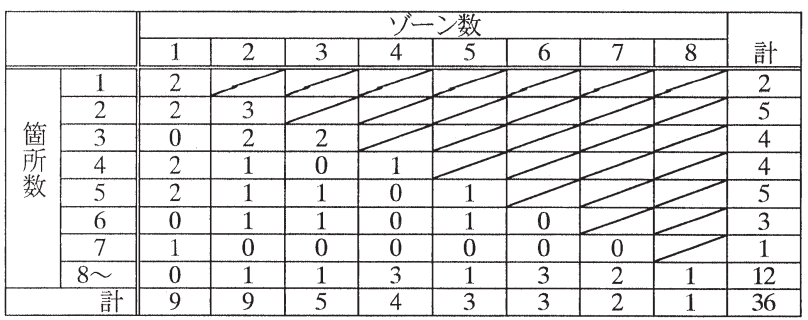

表 -13 回答者別の観賞公開庭数と訪問ゾーン数

\begin{tabular}{|c|c|c|c|c|c|c|c|c|c|c|}
\hline & \multicolumn{8}{|c|}{ ソ゚ーン数 } & \multirow[b]{2}{*}{ 人数竐 } \\
\hline & & 1 & 2 & 3 & 4 & 5 & 6 & 7 & 8 & \\
\hline \multirow{8}{*}{ 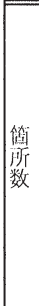 } & 1 & 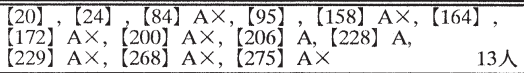 & & & & & & & & 13人 \\
\hline & 2 & 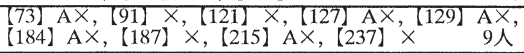 & $2_{2 \curlywedge}^{\lfloor 92 】 \times,(128 】 \times,}$ & & & & & & & 11人 \\
\hline & 3 & 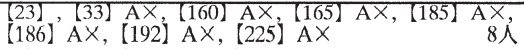 & $2{ }_{2}^{\lfloor 136\rfloor \times, 【 157\rfloor \times}$ & 【173】,1人 & & & & & & 11人 \\
\hline & 4 & 【19】 $\mathrm{A},\lfloor 30\rfloor,\lfloor 53\rfloor \mathrm{A} \times,\lfloor 66\rfloor \mathrm{A} \times,\lfloor 176\rfloor \mathrm{A} \times 5$ 人 & & & & & & & & 5人 \\
\hline & 5 & 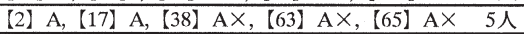 & $\lfloor 22\rfloor,\lfloor 222\rfloor \times 2$ 人 & & & & & & & 7人 \\
\hline & 6 & 【54】 $\mathrm{A} \times, 【 203 】 \mathrm{~A} \times$ & $\lfloor 102\rfloor,\lfloor 217\rceil \times 2$ 人 & & & & & & & 4人 \\
\hline & 7 & & & & 【152】,1人 & & & & & 1人 \\
\hline & $8 \sim$ & & 【59】, 【149】 2人 & 【147】,1人 & & & & & & 3人 \\
\hline & 效訴 & 42人 & 10人 & 2 2人 & 1人 & & & & & 55 人 \\
\hline
\end{tabular}

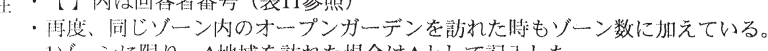

・・ソーンに限り、A地域を訪れた場合はAとして芘入した。

・当初、オープンガーテンを目的としていなかった劸合はメを記入した。 
1 ゾーン以内の行動者のうち Aゾーン内で行動している回答者 が 32 人であり, 全体の $58.1 \%$ と半数以上を占めている。また 1 ゾーン内の行動者の $76.2 \%$ あるる。北斎館を中心とする観光客 を誘引する集客力のある地域を中心に訪問者が行動していること がわかる。特に観賞者数の多い 2 割以上の観賞者, すなわち 11 人以上の観賞者のいた 5 箇所の公開庭のうち 3 箇所は, A ゾーン 内の店舗であり, 観光行動の一環として, 立ち寄られているとみ られる。公開庭の選定理由では, 特に「4.たまたま通りかかった」 とする回答が多く,これを裏付けている。

具体的に公開庭の観賞者の行動をみてみる。なお以下, 回答者 を特定する時は回答者番号を【】で示す（表 11 参照）。

回答者【157】は, 埼玉県から鉄道で小布施に来て, アンケー 卜票を小布施駅で受け取り, 小布施駅で返している。当初の訪問 目的には, オープンガーデンを含め,「緑のまつり」関連のイベ ントへの参加はなかった。しかし駅でオープンガーデンのあるこ とを知り, 公開庭 [46] [47] [62]の 3 箇所を観賞している。その立 地之行程をみると (図 3 ), 移動距離が比較的長いことがわかる。 パンフレットの情報から訪れる公開庭を選択し, シャトルバスを 利用して移動しているとみられる。

また回答者【217】は，埼玉県から自家用車で小布施町を訪れ， 町営松村駐車場に停め, そこでアンケート票を受け取り, 返して いる。オープンガーデンについては知らなかったとしている。し かし公開庭は［58］［59＜wide>[60＜wide>[63＜wide>[28＜wide>[69＜wide>の６箇所を観賞 している。その立地と行程をみると（図 4 ), 近くにある公開庭 を順に巡っていることがわかる。特に北斎館を挟んで反対地域に ある, 一般住宅地の公開庭にまで足を運んでいる。観賞している

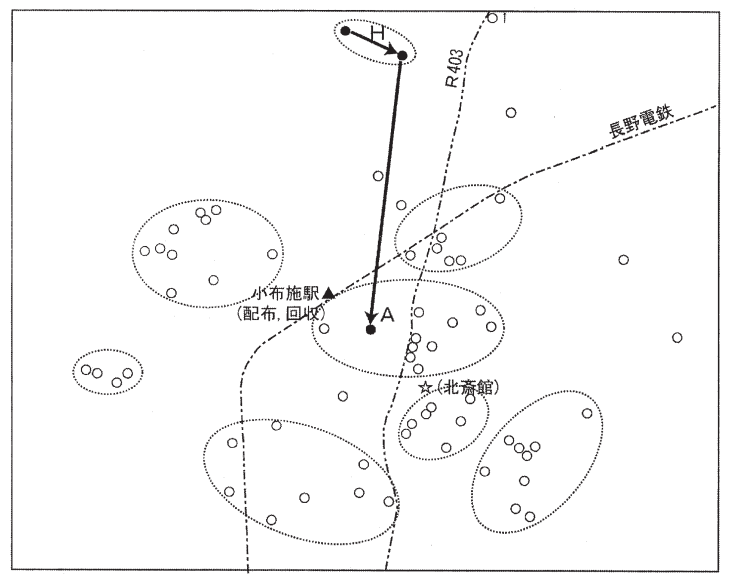

図 -3 回答者【157】の公開庭巡りの行程

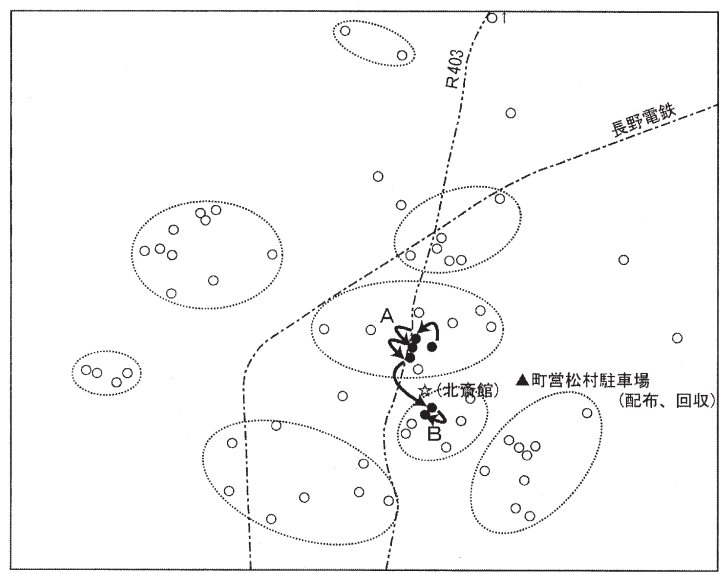

図 -4 回答者【217】の公開庭巡りの行程
A ゾーンの公開庭から北斎館附近は, 特に観光客向けの店舗が多 く連なっている。移動距離は短く, 徒歩で回遊している。

いずれもオープンガーデンを当初の目的としていなかった訪問 者が，公開庭を観賞している。

\section{7. 結論と考察}

本稿では, 来訪者の目的や行動等から, “信州おぶせ緑のかけ 橋まつり”の開催時における小布施オープンガーデンの意義や位 置づけを明らかにした。

通年的な仕組みであるオープンガーデンを関連イベントの一つ に加えることで, 来訪者の行動の選択肢は確実に増えている。再 訪者の約半数がこの機会に初めて公開庭にも足を延ばしている。 特に比較的広範囲に一般住宅地の公開庭も観賞しており，その行 動を支援するシャトルバスの運行によって，町内を回遊するとい う動機づけになっているとみられる。またオープンガーデンの主 旨や公開庭の位置は, パンフレット等の具体的な情報媒体がない と理解はできず，この期間に提供される「緑のまつり」の無料の パンフレットはその役割を担った。

「緑のまつり」開催日での来訪者へのアンケート調査であった が,「緑のまつり」を知らないで訪れる観光客, あるいはオープ ンガーデンを含めた「緑のまつり」の各種イベントを目的としな い観光客もいた。しかしアンケート回答者の半数はオープンガー デンによる公開庭を観賞し，結果として「緑のまつり」の参加者 となった。先行研究で明らかになった通常期に比べれば，観賞し た公開庭数は少なく, 行動範囲も狭い。これは公開庭の観賞を主 目的とした来訪者も同様である。しかし他の目的で小布施に来て 屯, 当地でイベントを知り, またオープンガーデンを知り, そし て実際に公開庭に立ち寄るという, 移動と観賞の行為が発生して いる。

このように期間限定ではあるが，シャトルバスの運行と無料パ ンフレットという交通手段と情報の提供が寄与し, 町内外の人た ちの「緑のまつり」への参加之理解において, オープンガーデン の果たした役割があった。オープンガーデンを「緑のまつり」の イベントに組み込むことによる相乗効果によって来訪者の行動が 多様になり，イベントを盛り上げることになった。

付記

本研究は，ユニオン造形文化財団ならびに道路緑化保全協会か ら助成を受けた。記して謝意を表したい。

\section{補注及び引用文献}

1 ）野中勝利（2002）：長野県小布施町におけるオープンガー デンの特徴と課題：ランドスケープ研究 65(5), 805-810

2 ) 相田明・進士五十八（2001）：先駆的事例を通じた我が 国におけるオープンガーデンの意義：東京農業大学農学 集報 46(3)，154-165

3 ）平田富士男ほか（2003）：わが国におけるオープンガー デンの地域経済への波及効果量の把握に関する研究：ラ ンドスケープ研究 66(5), 779-782

4 ) 野中勝利（2005）：日常的公開のオープンガーデンに掠 ける観賞者の行動特性一小布施オープンガーデンを事例 として一：都市計画論文集 40-3，847-852

5 ）小布施町役場は, このイベントに際して, 事前に公開庭 のオーナーを対象とした説明会を開き（2004 年 7 月 29 日）, 開催日当日の来客への応対について理解と協力を求めて いる。

6 ）配布数が確認できた 4 つの配布箇所以外は, 日常業務の 中で来訪者へのアンケート票の配布を依頼した箇所であ る。多忙な日常業務の中での作業であり, 確定した配布 実績までは捕捉できなかった。 